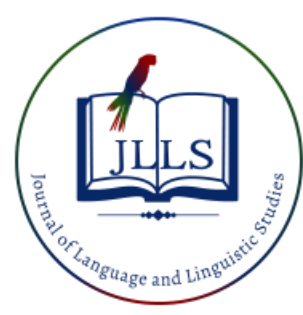

Available online at www.jlls.org

JOURNAL OF LANGUAGE AND LINGUISTIC STUDIES

ISSN: $1305-578 \mathrm{X}$

Journal of Language and Linguistic Studies, 16(3), 1251-1263; 2020

\title{
Pragmatics of overlapping talk in therapy sessions
}

\begin{abstract}
Nawal Fadhil Abbas ${ }^{1}$
APA Citation:

University of Baghdad, Baghdad, Iraq

Abbas, N. F. (2020). Pragmatics of overlapping talk in therapy sessions. Journal of Language and Linguistic Studies, 16(3), $1251-1263$.

Submission Date:24/03/2020

Acceptance Date:18/05/2020

Abstract

Cooperation in conversation is usually managed by the turn- taking mechanism where the interlocutors' turns are done according to certain rules, the most important of which is that one and only one speaker speaks at a time. And since talk can be used as a cure for the people who have troubles in their life, psychotherapy uses the field of conversation analysis as a procedure to deal with such troubles. Conversation analysis with all its essential facts helps therapists find out the reasons behind their patients' difficulties and predict the solutions for them. One of such essentials is the turn taking system, and more specifically is the 'overlapping talk'. In relation to this, the present study aims to show the reason behind the occurrence of overlap in therapy sessions and how it is managed and resolved. To do so, two scripts taken from two psychological therapy sessions are selected and examined using Sacks et al's model (1974) and Jefferson's model (1983). The study has come to the conclusion that the overlapping talk usually occurs because of the misjudgment of the transition relevance places (TRPs) due to the type of overlap whether transitional or progressional. It has also been noticed that the terminal overlap is used more frequently than the other types. Continuers such as 'yeah', 'ok', 'alright', 'aha', 'umm' are used by therapists to encourage the patients to go on with their talk.
\end{abstract}

(C) 2020 JLLS and the Authors - Published by JLLS.

Keyword: overlapping talk; recycling; resolving; therapy session; turn-taking system

\section{Introduction}

Conversation analysis is the field of studying talk. It is the systematic analysis of talk produced in everyday interaction. In other words, it is the study of talk-in-interaction, i.e., actual interaction. One way of approaching conversation is through examining what conversation analysis does. Moreover, it is based upon the transcribed tape-recordings of the naturally occurring conversations. This refers to the situations which are recorded as far as possible in the ordinary exposure of people's lives, as opposed to being arranged in advance in laboratories (Hutchby and Wooffitt, 2002, p. 14). It is also defined as "a describable domain of interactional activity exhibiting stable, orderly properties that are the specific and analyzable achievements of speakers and hearers" (Regina Wu, 2004, p. 34).

\footnotetext{
${ }^{1}$ Corresponding author. Tel: +9647702517018

E-mail addres: nawal.fadhil@ coeduw.uobaghdad.edu.iq
} 
Conversation analysis was evolved out of the ethno-methodological tradition in sociology and then developed by Garfinkel (1967). He was interested in studying the social experience so as to offer an understanding of "how the structures of everyday activities are ordinarily and routinely produced and maintained"(Ibid, pp. 37-8). This interest in studying the actual instances of social interaction was further developed in the work of Goffman (1981), who asserted that the ordinary activities of daily life were a crucial subject for study. Goffman's work showed that it was not impossible to study everyday events and situations and to explore from them non-trivial information about how human beings get involved in sociality. Then, he added that the study of talk was not merely a matter of narrowly concentrated linguistic descriptions of language. Rather, it was a reciprocal action with a system of rules and structures, not fundamentally linguistic in nature. This means that the study of language in completely linguistic terms could not accurately account for the nature of language-in-use. Garfinkel and Goffman (1967) supplied a motive for the development of the field of conversation analysis by setting up a concern for inspecting the orderliness of daily life and this was taken up by Sacks in the early 1960s. In his lectures, Sacks came up with an approach to the study of the social action where he attempted to investigate the social order by examining it through the practices of everyday talk. By the late 1960s and early 1970s, out of the work of Sacks and his colleagues, Schegloff and Jefferson, conversation analysis developed from sociology as an independent discipline oriented towards the comprehension of the structural texture of talk which impacted a number of social sciences that were interested in human interaction.

\subsection{Literature review}

The discipline of conversation analysis emerged from ethno-methodology, a regard for understanding the order gained within social interaction, and experimentally it was based on microanalytic studies. Sacks' approach to the study of conversation is identified with a view of talk as an event through which speakers accomplish things in a reciprocal action. Talk can, therefore, be strategically used to get communicative goals. For Sacks, this strategic employment of speaking is not a set of rules or recipes by which actions are achieved, rather, the production of interactional effects are accomplished through the application of talk in a certain context. For Sacks, conversation arrangement is orderly and this framework is manifested at all points. The job of the analyst is to figure out and prescribe the produced orderliness which is made by conversationalists during conversation. Conversation analysis, as the name of an approach to studying talk in interaction, is in some ways an inaccurate name for the approach, as the focus of conversation analysis is indeed much wider than conversation as it is usually understood. Liddicoat (2007, pp. 2-6) states that conversation analysts "do not find an inherent difference between the formal and the informal, the everyday and the institutional; rather they look at a talk in interaction as a social process promoted to recognize and understand the social situations in which speaking takes place".

However, conversation analysis is the study of recorded, naturally occurring talk in interaction. The question now what is the goal of studying such an interaction? Chiefly, it is to find out the way through which interlocutors respond to each other in a conversation with a special interest to know how series of actions are produced. In other words, the objective of conversation analysis is to reveal the implied reasoning procedures and sociolinguistic competencies underlying the production and interpretation of talk in organized sequences of interaction. The target of conversation analysis is to emphasize the generation and interpretation of talk-in-interaction as an orderly accomplishment that is oriented by the participants themselves. Hutchby and Wooffitt (2002, pp. 14-15) confirm that conversation analysis intends "to uncover the order of talk not from the perspective of how the interlocutors display for one another understanding of what is going on. Peräkylä, on the other hand, elaborates that 
Many conversation analytical studies discuss fundamental aspects of conversational organization that have the ability to make any action possible. These include turn-taking, repair (i.e., the ways of dealing with difficulties of hearing, speaking, or understanding), the general ways in which sequences of an event are constructed, and the ways in which the participants of interaction determine their relation to the utterances through gaze and body posture (2012, p. 27).

\subsection{Research questions}

This study is intended to provide answers the following questions:

1. What is the reason behind the occurrence of overlap in therapy sessions?

2. How overlap is managed and resolved in naturally occurring talk, including therapy sessions?

\section{Turn-Taking Organization}

Turn taking in the literature refers to the idea that when people converse, they usually choose who will speak next. When the topic is decided and when the conversation is initiated, the aspect of turn taking is realized. To Ghilzai $(2015$, p. 2), "knowing when it is possible or obligatory to take a turn in conversation is important to the co-operative department of discourse". Turn-taking organization, or mechanism, is one of the most important aspects of conversation where two interlocutors exchange roles in order to begin their speech. The turn-taking mechanism may actually diverge between cultures and between languages. In ordinary conversation, it is very weird to see any allocation of turns in advance (Kato, 2000, p. 14). In ordinary interaction, turn-taking is regarded as a remarkable goal. One of the essential aspects in conversation is that none of the two parties knows in advance how many turns they will take, how long each turn will be, whether or not another person will join in, what are the topics of interest, and so on. Moreover, the length of a turn is not set in advance. Wooffitt (2005, p. 26) emphasizes that

despite these and considerable other uncertainties, it is extremely likely that turn change will be achieved in an orderly fashion: there will be highly few periods where more than a single party is talking, and these will be comparatively short-lived, and successive turns will be built so as to reduce any gap or delay before the next speaker, illustrating that there is an impressive extent of allocation timing in the placement of turns in relation to each other.

Generally, the turn taking mechanism depends on a number of rules. Sacks, Schegloff, and Jefferson (1974) describe the way interlocutors construct and allocate turns in a very organized way. They also explain the system of turn taking as a model, which is based on turn taking phenomena. The pattern focuses on the idea of 'turn constructional units'. They state that as a speaker arrives to a 'transitionrelevance place (TRP)', the next rules apply. Such rules are stated below:

- If the current speaker has nominated another speaker, speaker change takes place (rule 1a)

- If the current speaker has not nominated another speaker, any participant in the conversation may take the turn, and speaker change can take place (rule 1b)

- If the current speaker has not nominated another speaker, and no other person has self-nominated, the current speaker may continue (rule 1c)

- These rules apply at every transition-relevance place (rule 2)

Sacks et al's (1974) system of turn-taking is characterized by being context independent since it does not depend on the details of the situation to operate. People usually manage turn-taking in public, 
at work, and in their homes. Besides, it can be noticed between lovers and friends, and between colleagues and strangers. It can also be used in periods of economic boom and during recessions. In addition to being context dependent, this system is also context sensitive in that with any actual similar activity of the above options, it will be managed on the basis of having a turn-by-turn. This is simply because these turn-taking choices are connected with the finishing of each 'turn construction unit' "unless the current speaker has indicated that she is involved in an activity which requires the temporary suspension of turn-taking, for example, telling a story or a joke" (Wooffitt, 2005, p. 29).

There are a number of aspects related to the turn-taking mechanism. One of such aspects is 'overlap' or overlapping talk. It is explained in detail in the next sections supported with examples.

\subsection{Overlap}

The terms 'overlap', 'overlapping talk', 'overlapping speech' refer interchangeably to talk occurring at the same time by two or more users of language, i.e. interlocutors. One of the rules of conversation is that one speaker is to speak at a time and that the other speakers are to wait until the first speaker finishes his/her turn. The reason for this rule is not to allow two or more participants to talk at the same time as this will turn the conversation into chaos. That is why it is important to avoid the overlapping talk and this is an essential part in conversations; "even to the degree that waiting for one's turn when talking is one of the first things that little children are taught" (Stolt, 2008, p. 6).

Overlap is generally regarded, to most linguists, to be of two types with respect to turn-taking: either competitive or non-competitive. This classification is important for two reasons: to catch the essence of the turn-taking system and to account for all instances of simultaneous talk. A competitive overlap is used to refer to cases of simultaneous talk, which takes place "before the current speaker has reached a potential completion in his/her turn and whose purpose is to take or at least defy the turn of the current speaker" (Ibid, p. 16).

\subsubsection{Types of overlapping talk}

One-at-a-time talk means that the participant in a conversation cannot process information from more than one source at a time. Moreover, much of the overlapping talk cannot be heard by the other party. As such, some overlapping talk is classified as inadvertent or accidental, whereas the other type of overlap is classified as 'violative' or intentional. Below is an account for both types.

\section{Accidental:}

A current listener involved in a conversation usually monitors the talk of the current speaker while waiting for upcoming transition relevance places. Furthermore, a current listener attempts to identify such places in which the roles of a speaker and a listener could alternate. This leads us to the idea that people are professional in doing this which is due to the fact that the transition is very quick to be done in seconds. In this type of overlap, there is no intention on the part of the listener to willfully interrupt the speaker. The overlap occurs because of the misjudgment on the current listener to realize an upcoming transition relevance place. For example in:

A: She has passed her exam, // hasn't she?

B:

Yeah.

B misjudges the transition relevance place before the tag question resulting in an inadvertent overlap with A in the use of 'Yeah' due to the very short pause immediately after 'She has passed her exam'. 


\section{Intentional:}

It is well known that the rules of turn allocation operate in the transition relevance places. Therefore, in case any participant in a conversation tries to apply these rules at any place, away from the transition relevance place, this will lead to a violation of the turn allocation procedure. In other words, when it is, contrary to the above point, not possible to argue that the listener misjudges a potential upcoming transition relevance place, the overlap is interpreted as 'violative interruption' that willfully does not pay attention to the rules of turn allocation in conversation. For example in:

A: I can't guarantee that he's // coming soon

B:

//you can

C:

too bad

Both B and C willfully interrupt A's proposition since their talk does not occur at a possible transition relevance place which is supposed to be after 'coming soon' not before it.

To Sacks et al. (1974), there are four kinds of overlapping talk:

- Terminal overlaps: In this type the interlocutor is shown to start up at a point where he/she thinks that the previous speaker is done with the previous turn. Here the overlap seems to project its almost immediate self-liquidation, although this result is not inevitable. This feature avoids the need for special practices for deciding the overlap.

- Continuers: These are also referred to as meta-discourse markers (cited in Hussein, Khalil \& Abbas, 2018) including $u h \mathrm{huh}, \mathrm{mm} \mathrm{hm}$. They are context-fitted assessment terms by which recipients of others' talk can show precisely that they understand what the current speaker in the track of an extended turn at talk is saying although the turn is not finished yet. Continuers also do not mobilize special practices for the management of simultaneous talk.

- Conditional access to the turn: In this case, a speaker in a turn-in-progress invites another to talk in his turn's space but this access is conditional. The most familiar cases are (a) when the current speaker is invited to help in recalling or finding a word, a name of a person for instance, that the recipient-of-record cannot retrieve; and (b) collaborative utterance construction, where a speaker starts an utterance and gives it to another to complete it. They are both of great importance in making interaction go smoothly.

- Chordal or choral formats: Here, forms of talk and activities are dealt with co-participants not as one by one, but as simultaneous acts. An example of this case is laughter, whose occurrence can work out as an invitation for others to laugh at the same time rather than after the incidence. Other such events include collective greetings, leave-takings, and congratulations when hearing some good news. Such incidences are done chorally but they are not competitive (Schegloff, 2000, p. 5).

Jefferson (1983, p.12) describes three distinctive main categories of overlap onset:

- Transitional overlap: This takes place at or close to a transition-relevance place (TRP). This type sometimes takes place as a result of a minor mistake on the part of the speaker.

- Recognitional overlap: It usually occurs before a TRP in cases when interlocutors hear enough of the current turn to be able to comprehend what the current speaker is trying to say.

- Progressional overlap: It appears when 'a problem arises towards the completion of a turn and it is usually manifested in the form of hitches. 


\subsubsection{Resolving overlapping talk}

In conversations, when there is overlapping talk, interlocutors usually try to correct the situation by returning to the state of having one speaker and only one as soon as possible. The question now: how can this be achieved? This can be handled by using two main strategies:

1. Dropping out

In an example like:

A: He'll have to sing a lot better.

B: //He was trying...

C: He never had the opportunity to show how good he was.

Not selecting the next speaker pushes both B and C to self-select and the result is an inadvertent overlap which is removed by B's dropping out relinquishing the claim to a turn at talk. Misjudging the transition relevance place also results in an inadvertent overlap that can be resolved by dropping out a turn.

\section{Competitive allocation}

When interlocutors are not willing to relinquish their turn, the result is a competitive allocation, i.e., one or more of the interlocutors compete to either retain their turn at talk or to take over the turn at talk. This type of allocation takes place at moments of both inadvertent and violative interruptions. Consider the following example:

A: Can you help me with the map reading or not?

B: //Yes....erm...but...

C: Yeah, BUT I CAN'T GET THERE by myself, you know.

Since B and C overlap at the transition relevance place at the end of A's question, it is an inadvertent overlapping talk due to the self-selection of both of them. B seems hesitant and immediately drops out while $\mathrm{C}$ competes and upgrades his talk by raising his voice in line 3 and this is represented by the use of capital letters. So here the competitive allocation procedure is used to remove the overlapping talk.

\subsubsection{Recycling}

It is quite common that overlapping talk cannot be heard properly. Besides, it is well known that in a collaborative conversation the current speaker strives to ensure being attended to, understood and eventually heard. The problem now how could a participant in a conversation ensure the hearing of an important part of the conversation when that part is overlapped with the talk of another person? The problem can be solved by what is referred to as 'recycling'. Recycling (which is usually represented by an asterisk *) means re-presenting that part of the conversation which has been obscured and then unheard because of the overlap. The following example clarifies this point:

A: To whom has she got married?

B: // who told.....

C: She got married.... * She got married

to her brother's friend.

Here, A does not select the next speaker for the question and the result is a violative overlap due to $B$ and C's attempts to answer the question, i.e., self-selection. As $C$ continues with her turn, she recycles that part of the utterance that has been overlapped, 'She got married' before completing the utterance with 'to her brother's friend'. 


\section{Method}

\subsection{Data selection}

In order to achieve the aim of the study, which is already preset "to show the reason behind the occurrence of overlap in therapy sessions and how it is managed and resolved", the researcher of the present study has selected two scripts taken from different psychological therapy sessions to detect where the overlap usually occurs and how it takes place, what are the reasons for its occurrences, when and how? All these questions will be explained in the section of "Analysis and Discussion" below.

Each script will be divided into extracts and each extract will be thoroughly examined according to the type of overlapping talk used, by the patient and/or the therapist, whether accidental or intentional and according to the four types of Sacks et al.'s model (1974). Besides, the researcher will rely on Jefferson's classification of overlap onset (1983) to show the reasons. After identifying the overlapping talk and specifying its type, the researcher will show how it is resolved so as to ensure the continuity of the session. The interruptions and the overlaps in the extracts are marked with parallel slant slashes (//) and the recycling of the ceased overlapping talk is represented by an asterisk $(*)$.

\subsection{Data analysis and discussion}

In this section, the researcher analyzes the data, then discusses the results of the analysis.

\section{Script 1}

This script is about a middle-aged lady called Julie who is 48 years old. She is seeing her General Practitioner because she has some anxiety symptoms. She is currently sick off from her job as a 'bank clerk'.

\section{$1 \quad$ P: I get chest pains $/ / \ldots$}

$2 \rightarrow$ T: $\quad$ aha

3 P: I can't catch my breath; it's making me feel funny talking to you about it//...

$4 \rightarrow T:$

5 P: and, um, so my heart starts to race, I can't get my breath and then I get chest pains and I get very afraid that I'm gonna have a heart attack.

$6 \rightarrow T$ : right, right and you're feeling a little bit anxious just here with me.

$7 \rightarrow$ P: I am $/ / \ldots$

$8 \rightarrow \mathrm{T}: \quad$ ok

9 P: yeah, just talking about it.

In this extract between the patient Julie $(\mathrm{P})$ and the therapist $(\mathrm{T})$, the patient speaks first. There occurs an overlapping talk in which the two have their own reasons to come across each other. In lines 2, 4 and 8 , the therapist is trying to show the patient an awareness to what she is saying. This way the therapist is giving the patient a sign of continuing to explain her problem. Here, the therapist is not competing with the patient for the turn, therefore, this is a non-competitive overlap and also the therapist uses such expressions as (aha, right, and ok) to show understanding, thus, they are 'continuer' overlaps. In other words, this is an inadvertent overlap since there is no intention on the part of the therapist to willfully interrupt the patient. There seems to have a misjudged upcoming transition relevance place on the part of the therapist. In lines 5, the patient is not to be seen interrupting, but she continues what she has started in line 3; at the same time, it is a non-competitive overlap for the purpose of continuity on the part of the therapist (collaborative utterance construction), i.e., the therapist's intention is to help the patient to explain things properly; therefore, it is a conditional overlap. 


\section{$1 \rightarrow P$ : because it just seems to have come out of the blue, I've never suffered from anything like} this // before ...

2 T: it sounds like he's getting to the end of his lather, but it also sounds like you're pretty fed up with the whole thing as well //...

3 $\rightarrow \mathbf{P :}$

yeah yeah

The overlap in this extract illustrates the therapist's attempt to summarize the whole thing the patient has been explaining. The patient's proposition in line 1 is incomplete as the dots show. The overlap commences on the word 'before' in line 2. This kind of overlap is non-competitive because the therapist does not intend to hold the floor, but just to clarify stuffs for the patient (i.e., terminal). On the whole, this overlap is not considered violative, rather it is inadvertent despite it ignores the rules of turn allocation in conversation. The interesting point here is that the patient agrees to what is proposed by the therapist's intentional overlap when she positively responds with 'yeah' twice. Moreover, the therapist's overlap is described as 'recognitional' due to the idea that she has heard enough from the patient to be able to comprehend what she is in the course of saying.

\section{T: just to make sure I've got the right way around it. It began; it began six months ago,} pressure at work// ...

$2 \rightarrow$ P: $\quad$ yeah

3 T: you went to town, had the first of these attacks $/ / \ldots$

$4 \rightarrow$ P: $\quad$ um, um...

5 T: and since then you've had some more of them $/ / \ldots$ $6 \rightarrow P$ : yeah, yeah

In this extract it is the therapist who seems to initiate propositions and the patient is in a position to respond and her responses are introduced in the form of overlapping talk. This is again a non-competitive overlap by which the patient is trying to confirm the therapist's information and thereby the patient clears the path for the therapist to explain, and obviously they are 'continuer' overlaps. The three continuers in lines 2,4 , and 6 , to the patient, come near a transition relevance place since the current speaker, i.e., the therapist, has reached a potential completion in her turns in lines 1,3 , and 5 . The overlaps are all terminal and function as transitional since the patient seems to agree with her responses by using 'yeah', um, um', and 'yeah, yeah'.

\section{$1 \rightarrow T:$ and now it's kind of got to the point where} you don't want to go out//...

2 P:

$3 \rightarrow$ T: you don't go by yourself $/ / .$.

4 P:

no, I don't know.

$5 \rightarrow$ T: right, right.

no, I don't want to risk it to be honest.

In line 1 the therapist engages the patient in a talk which is overlapped in line 2 by the patient thinking that the therapist has reached a transition relevance place. In other words, the non-observance by the patient has led to a non-competitive overlap of the terminal type. In line 3, the therapist resumes and once again, she faces another non-competitive overlap, but this time it is conditional, and more specific, it is collaborative since the interlocutor initiates an utterance and gives it to another one to complete it. That is why the patient thinks that the therapist has just finished her turn and that she inquires the truth of her going alone. So, the patient immediately begins to speak with 'no, I don't want to risk it to be honest'. Realizing that the therapist hasn't done with her turn, she makes her sentence short and brief and the result is a 'terminal' overlap.

$1 \rightarrow T$ : and then the minute it starts to change as you click it, you notice it, and then you start to get anxious thoughts so you might $/ / \ldots$ 
2 P:

start worrying, I really do

$3 \rightarrow$ T: yeah.

$4 \rightarrow \mathrm{P}$ : I keep thinking is it going to be now, you know, is my heart going to stop beating $/ / . .$.

5 T: right so you got those kinds of anxious thoughts.

$6 \rightarrow P:$ yeah, yeah

Line 1 shows another kind of overlap in which the therapist and the patient are competing for the turn. The therapist tries to interpret what happens to the patient when she gets anxious thoughts. The patient interrupts using a competitive turn and takes the turn adding more details to the therapist's proposition. So, this is a clear example of a competitive overlap, of the terminal type, and the therapist drops out while the patient continues with her talk. It is a transitional overlap in the sense that it comes near the transition relevance place and the speaker is in a way does not reach the patient's problem in having worries. The therapist's reply in line 3 'yeah' supports this argument. In line 5, the therapist this time interrupts the patient in line 4 using a non-competitive overlap, making use of the non-observance of the transition relevance place. The overlap this time is of the recognitional type since it is based on the therapist's recognition of the patient's proposition.

\section{Script 2}

The second script is about a man called John Riley. He is a 36 year old and he is seeing his psychiatrist because his General Practitioner has already raised some concerns about him. His job is a car mechanic and he currently lives with his parents.

1 T: my name is Dr. //....

$2 \rightarrow \mathrm{P}: \quad$ no your proper name isn't doctor*...

3 T: $\quad *$ at work I am Dr. Beddy

$4 \rightarrow \mathrm{P}$ : you're not a doctor, doctor, who, doctor who, didly dang, woddly dang

[Laughter from John], it's good that, do you watch that it's fantastic that program?

5 T: ok.

In line 2, the patient overlaps with the therapist's turn trying to hold the floor with 'no your proper name isn't a doctor'. He interrupts her intentionally thinking that she is lying to him so he predicts that she has finished her turn and then he starts speaking. This kind of overlap is terminal and it is competitive because the patient wants to take the turn. The therapist on her part tries to resolve the overlap by relying on the competitive allocation and trying to regain a turn at talk at a point where there is no appropriate transition relevance place to produce 'at work I am Dr. Beddy'. In other words, as the therapist continues with her turn at talk, she recycles that part of her talk that has been overlapped by the patient. This is done because the therapist wants to re-present the information which has been obscured by the violative interruption.

1 P: now what is $/ / \ldots$

$2 \rightarrow$ T: $\quad$ John... can I ask you how old are you, John?

3 P: how old, I, oh don't. You're as old as the woman you feel, aren't you, aye? //[Laughter from John]

4 T: right, ok.

In line 2, the therapist interrupts paying no attention to any transition relevance place and directs a question to stop the patient's fruitless talk in an attempt to take the turn back. So, the two are competing for the turn (violative overlap). Both of them are battling for talking; the therapist is trying to collect some information about the patient who is not replying positively. However, the patient once again overlaps in the form of laughter after the tag question 'aren't you, aye?' which is considered an appropriate transition relevance place for the other interlocutor to reply. So this type of overlap is transitional.

1 T: shall we perhaps, I tell you what $/ / \ldots$

$2 \rightarrow \mathbf{P}:$

ok, now, let's go back to this, this is important. 
3 T: yes, that's a good idea, yup ok

4 P: this is why I am here to talk to you about this//...

$5 \rightarrow \mathrm{T}$ :

6 P: to tell you what is going on.

ok, right.

In this extract there is a competitive overlap in line 2 which is quite evident. The therapist just wants to question the patient who does not seem interested at all. That is why he overlaps and produces a proposition even before the therapist initiates his question. Therefore, the patient creates overlapping talk to hold the floor. This is a terminal overlapping and progresstional at the same time since the patient intends a development towards the end of the therapist's turn in line 1 . In line 3 , the therapist decides to give the patient space to talk and that is really obvious in the assessment following his speech "that's a good idea". Then, in line 2, she shows understanding of his speech saying "ok, alright", which is an overt overlap, but non-competitive and the purpose is to give an instruction for continuity. The overlap here is continual and recognitional.

1 P: so that's why he sends me here to see you to tell you all about it?

2 T: right, ok, tell me//...

$3 \rightarrow \mathrm{P}: \quad \quad$ ok, right, well it's, I've got*...

$4 \rightarrow \mathrm{T}$ : $\quad \quad / /$ tell me about it; tell me what's going on?

5 P: * I've got my various bits and pieces here, I find in the papers like you know the football results

6 T: right.

In line 2, the therapist is interrupted by the patient somewhere near 'tell me', which can be a transition relevance place. So, it is a non-competitive overlap. Line 3 ends up with a violative overlap on the part of the therapist to gain the turn and force the patient to answer specifically 'tell me about it; tell me what's going on'. This overlap is conditional in the sense that the therapist wants the patient to be more specific. In line 5, the patient recycles his interrupted turn in line 3 'I've got...' already violated by the therapist's interruption. So the competitive overlap, i.e., terminal and transitional, is done by the two interlocutors where both of them are trying to hold the floor.

1 T: He talks to you?

2 P: yeah he talked to me//....

$3 \rightarrow \mathrm{T}$ : $\quad$ ok, alright.

$4 \quad$ P ... and told me//...

$5 \rightarrow$ T: $\quad$ alright

6 P: I'm doing a really good job//...

$7 \rightarrow$ T: $\quad$ ok

8 P: and I'm fantastic//...

$9 \rightarrow$ T: $\quad$ so God talks to you

10 P... and that I'm really wonderful $/ / \ldots$

$11 \rightarrow \mathrm{T}: \quad$ aha, aha.

Towards the end of the session, the conversation seems smoother. In lines 3,5, 7 and 11, the therapist is seen to show her understanding of what the patient is saying by using non-competitive overlaps through the use of the continuers 'ok, alright', 'alright', 'ok', and 'aha, aha'. In these turns, the therapist's intention is not to overlap with the patient, but to give him a mark to continue speaking, i.e., a sense of relaxation. So this is 'continuer' overlap and at the same time recognitinal. In line 9, the therapist wants to inquire some facts, but this is of no use with the patient's attempts to hold the floor. So, the therapist shifts back to 'continuer' overlap. 


\section{Conclusion}

Turn-taking mechanism or organization refers to the process through which people properly manage their conversation. In naturally occurring conversation, there is a rule that one person is to speak at a time while other participants are to hold up until the first speaker finishes his turn. This mechanism involves three possibilities that logically control and shape the relationship between speakers and listeners with regard to the selection of the next speaker. Overlap (or overlapping talk), which is an aspect of everyday conversation, has been identified to be critically examined in two scripts selected from two different therapy sessions. Based on the analysis of the two scripts, it is shown that the overlapping talk usually occurs because of the non-observance or misjudgment of the transition relevance places or being near to them. It has also been noticed that terminal overlap is used more frequently than other types of overlap. Continuers such as 'yeah', 'ok', 'alright', 'aha', 'umm', also known as context fitted assessment terms or back channels, are used by the therapist to encourage the patients to continue their turns. They are indicators of listening and paying attention. They are used to show understanding, add details or inquire certain facts. On the whole, they are considered helpful to the recipient to comprehend that the speakers are on the track of an extended turn at talk which is not yet complete. Besides, conditional access to the turn is used by the therapist to gain information from the patient by inviting him/her to talk in her turn's space. Finally, it is worth to mention that in the first script, the non-competitive overlap has dominated the conversation between the therapist and the patient. While in the second script, most of the overlapping talk is seen on the part of the patient who tries hard to hold the floor.

\section{Ethics Committee Approval}

The author(s) confirm(s) that the study does not need ethics committee approval according to the research integrity rules in their country (Date of Confirmation: August 27, 2020).

\section{Acknowledgements}

The researcher of the present study is indebted to the College of Education for Women, University of Baghdad, Al-Jadiriyya, for carrying out this study.

\section{References}

Abbas, N., Raja Suleiman, R., and Abdul-Manan, S. (2010). A conversation analysis of some excerpts from Montgomery's Anne of Green Gables. International Journal of Language, Society and Culture, $31,52-61$.

Garfinkel, H. (1967). Studies in Ethnomethodology. New Jersey, Englewood Cliffs: Prentice-Hall.

Ghilzai, S. (2015). Conversational analysis of turn taking behavior and gender: Differences in multimodal conversation. European Academic Research, 3(9), 10100-10116.

Goffman, E. (1981). Forms of Talk. Philadelphia: University of Pennsylvania Press.

Hussein, K., Khalil, J. and Abbas, N. (2018). Metadiscourse discourse markers in Master thesis abstracts of American and Iraqi English theses. Arab World English Journal, 9(4), 347-3

Hutchby, I. and Wooffitt, R. (2002). Conversation Analysis: Principles, Practices and Applications. Cambridge: Polity Press. 
Jefferson G. (1983). Notes on some orderliness of overlap onset. Tilburg papers in language and literature. Tilburg: University of Tilburg.

Kato, F. (2000). Discourse Approach to Turn-Taking from the Perspective of Tone Choice Between Speakers. United Kingdom: University of Birmingham.

Liddicoat, A. (2007). An introduction to conversation analysis. London: Continuum.

Mey, J. (2001). Pragmatics: An introduction. Oxford: Blackwell.

Perakyla, A. (2012). Conversation Analysis. Oxford: Blackwell.

Perakyla, A., Antaki, C., Vehviläinen, S. and Leudar, I. (2008). Conversation Analysis and Psychotherapy. Cambridge: Cambridge University Press.

Regina Wu, R. (2004). Stance in Talk: A conversation Analysis of Mandarin Final Particles. San Diego: John Benjamins Publishing Company.

Sacks, H. (1992, 1995). Lectures on conversation. Oxford: Blackwell.

Sacks, H., Schegloff, G., and Jefferson, G. (1974). A Simplest systematic for the organization of turntaking for conversation. Language, 50(4), 596-735.

Schegloff, E. (2000). Overlapping Talk and the Organization of Turn-Taking for Conversation Language in Society. Cambridge: Cambridge University Press.

Schegloff, E. (2000). Overlapping talk and the organization of turn-taking for conversation. Language in Society, 29(1), 1-63.

Stolt, M. (2008). The many Faces of Overlap: Non-Competitive Overlap in Conversations between Finnish and British Speakers of English. Jyvaskyla: University of Jyvaskyla.

Wooffitt, R. (2005). Conversation Analysis and Discourse Analysis: A Comparative and Critical Introduction. London: Sage Publications.

Yule, G. (2010). The study of language ( $4^{\text {th }}$ ed.). Cambridge: Cambridge University Press.

\section{Terapi seanslarında örtüşen konuşmanın pragmatikleri}

\section{$\ddot{O} \mathbf{z}$}

Sohbet sırasında işbirliği genellikle, muhatapların dönüşlerinin belirli kurallara göre yapıldığı, en önemlisi her seferinde bir ve sadece bir konuşmacının konuşması olan sıra alma mekanizması tarafından yönetilir. Ve konuşma, hayatında sıkıntı yaşayan insanlar için bir çare olarak kullanılabileceğinden, psikoterapi bu tür sorunların üstesinden gelmek için konuşma analizi alanını bir prosedür olarak kullanır. Tüm temel gerçeklerle konuşma analizi, terapistlerin hastalarının zorluklarının arkasındaki nedenleri bulmalarına ve onlar için çözümleri tahmin etmelerine yardımcı olur. Bu tür temel unsurlardan biri sıra alma sistemidir ve daha spesifik olarak "örtüşen konuşma" dır. Bununla bağlantılı olarak, bu çalışma terapi seanslarında örtüşmenin ardındaki nedeni ve bunun nasıl yönetilip çözüldüğünü göstermeyi amaçlamaktadır. Bunu yapmak için, iki psikolojik terapi seansından alınan iki senaryo seçildi ve Sacks ve diğerlerinin modeli (1974) ve Jefferson'un modeli (1983) kullanılarak incelendi. Çalışma, örtüşen konuşmanın genellikle geçiş uygunluk yerlerinin (TRP'ler) geçiş türü veya aşamalı örtüşme türüne bağlı olarak yanlış değerlendirilmesinden kaynaklandığı sonucuna varmıştır. Uçbirim örtüşmesinin diğer tiplere göre daha sık kullanıldığı da fark edilmiştir. "Evet", "tamam", "pekala", "aha", "umm" gibi devam eden ifadeler, terapistler tarafından hastaları konuşmalarına devam etmeye teşvik etmek için kullanılır.

Anahtar sözcükler: örtüşen konuşma; geri dönüşüm; çözme; terapi seansı; sıra alma sistemi 


\section{AUTHOR BIODATA}

Nawal Fadhil Abbas got her PhD in English Language and Linguistics in 2014 from the school of Humanities, Universiti Sains Malaysia. Now she is an assistant professor teaching at the College of Education for Women, University of Baghdad. Her field of study is Semantics and Pragmatics. Other fields of interest include Critical Discourse Analysis, Critical Stylistics and Corpus Linguistics. You can reach her publications at: Nawal F. Abbas - Google Scholar Citations. 